International Journal of Agriculture and Environmental Research

ISSN: 2455-6939

Volume: 06, Issue: 05 "September-October 2020"

\title{
ALLELOPATHY IN ACACIA MANGIUM WILLD AS A STRATEGY FOR ACQUIRE SUCCESS IN NEW ENVIRONMENTS AND POTENTIAL USE IN CONTROLLING OTHER INVASIVE SPECIES.
}

\author{
Schirley Costalonga ${ }^{1, *}$, Maria do Carmo Pimentel Batitucci ${ }^{1}$ \\ ${ }^{1}$ Universidade Federal do Espírito Santo. Plant Biology post-graduation program. \\ Avenida Marechal Campos, 1468, CEP 29.040.090, Vitória, ES, Brasil. \\ *Corresponding Author
}

DOI: https://doi.org/10.51193/IJAER.2020.6502

\begin{abstract}
Biological invasion is currently one of the main causes of biodiversity loss and difficult protection and recovery actions of ecosystems. Despite being an emerging area in plant ecology, few studies investigate which are the mechanisms used by alien species that make them successful in new habitats, like the release of secondary metabolism compounds that will act on development and growth of others. In Brazil, Acacia mangium Willd threat the biodiversity even in protected areas. Thus, the aim of this work was evaluated the allelopathic effect of $A$. mangium Willd leave extract over L. sativa, L. leucocephala and U. brizantha seeds. Leaves were collected from Parque Estadual de Itaúnas, ES, Brazil, macerated in ethyl alcohol for five days and submitted to rotatory evaporation. Metabolites classes were identified by phytochemical tests. For allelopathic bioassay, seeds of each plant tested were treated with water or one of four concentration of the extract $(1,5,10$ and $50 \mathrm{mg} / \mathrm{mL})$. Phytochemicals tests indicated the presence of triterpenos, saponins and tanins. As the allelopathic potential, the extract not only reduced germination of $L$. sativain 5 and $10 \mathrm{mg} / \mathrm{mL}$ but also affected the germination speed index, germination mean speed, radicular length and radicles length speed index. $50 \mathrm{mg} / \mathrm{mL}$ took the full inhibition of germination. The invasive species L. leucocephala and $U$. brizantha also were affected by extract, although $U$. brizantha has been more sensitive to allelochemicals; this open a possibility of using an invasive species to control others and demonstrate the resistance of $L$. leucocephala even under adverse conditions.
\end{abstract}

Keywords: Allelopathy, alien species, Acacia mangium Willd, invasion ecology. 
International Journal of Agriculture and Environmental Research

ISSN: $2455-6939$

Volume: 06, Issue: 05 "September-October 2020"

\section{INTRODUCTION}

Earth's life history is deeply marked by native species destruction by alien species; the fossil record of the last 25 millions of years, along with other evidences, indicate that terrestrial organisms are in constant movement due to geological events that moved the continental plates, leading to the exchange of whole sets of species (Lowe et al, 2004; Sax, Stachowicz and Gaines, 2005). By having biota with different characteristics due to speciation phenomenon, each continent has the capacity to provide invaders to other places (Reichard and White, 2003); however, in the last century, this phenomenon is occurring with greater speed and frequency due to human contribution.

Human beings carries species beyond their natural barriers since from the beginning of agriculture, but it was with the discovery and occupation of new lands in the XV century that the phenomenon was highlighted (Sampaio and Schmidt, 2013), facilitating the overcome of ecological barriers and allowing the adaptation of organisms to environmental conditions unknown and resulting in significant increase in the occurrence of alien species on the globe witnessed today.

Second cause of biodiversity loss (first on islands and protected areas), biological invasion was first reported by Charles Darwin in his work The Origin of species in 1859; Wallace, in 1890, cited the Norway rat invasion as induced by human action (Vitule and Prodocimo, 2012). But it was with the Charles Elton's book (1958) entitled Ecology of Invasions by animals and plants (Reichard and White, 2003; Moro et al., 2012) that the ecology of invasions had its beginning (Petenon and Pivello, 2008); the author featured the theory that rich diversity communities are more resistant to invasion than those with low biodiversity, to credit to globalization phenomenon an active contribution to the spread of organisms to new habitats (Barnes, 2014) and warn the need to expand the knowledge about these species for the establishment of effective control strategies (Cadotte, Mcmahon and Fukami, 2005; Matos and Pivello, 2009).

As Ceccon (2013), biological invasion occurs differently in each environment, since some are more susceptible than others to this process. Are those with low diversity, which have climatic and environmental similarity to the region of origin of invasive biota as well as those who suffered degradation events (Matos and Pivello, 2009; Ceccon, 2013).

An exotic species to become invasive if overcome three evolutionary filters: historical or geographic filter that isolates the species in their place of origin; physiological or environmental filter; and biotic filter, that is the interactions relationship between native and alien species (Lorenzo and Gonzáles, 2010); for this, it uses a variety of strategies, ranging from high germination and growth rate to the production of allelopathic compounds that interfere with the 
International Journal of Agriculture and Environmental Research

ISSN: 2455-6939

Volume: 06, Issue: 05 "September-October 2020"

development of other plants and to assist in establishing in new environments. This phenomenon is called allelopathy and can be defined as the interference (direct or indirect) caused by the release in the environment of natural substances derived from the secondary metabolism and can affect positively or negatively the development of other plants (Lima et al., 2004; Rizvi, 2012). According to Rizvi (2012), allelopathy is a form of biochemical interactions between plants; for authors like Rice (cited by Rizvi, 2012; Cheng and Cheng, 2015), this term can be extrapolated to the effects - beneficial or harmful - exercised by biomolecules also released by microorganisms.

The perception of the existence of allelopathy occurred since the beginning of agriculture; the first record about phytotoxicity of a plant on the development of another occurred in 300 a.D by Theophrastus, who suggested that Cicerarietinum exhausted the soil where it was, limiting the emergence of other species (Alizadeh, 2011; Rizvi, 2012). However, its importance in the biological invasion process began to be explored only recently by researchers (Meiners and Kong, 2012), whom seek to determine the mode of action for this interaction and demonstrate their contribution to the ability of some exotic species become dominant in the invaded community (Mathias et al., 2015). Unfortunately, this kind of research is still scarce and never associated with the possibility of to be a useful tool in control of new invasions, opening a research opportunity that can help understand the mechanisms used to dominate new environments and also provide opportunity for the development of tools that enable your effective control without further affect ecosystems impacted by them.

Brazil has two of the biggest world's hotspots of biodiversity but needs much more evolution on the issue of invasive species (Zenni and Ziller, 2011), although considerable advances have occurred in recent years. As tropical country, Brazil is highly vulnerable to biological invasion because offers favorable climatic conditions (Santana and Encinas, 2008). Furthermore, high rate of urbanization growing is able to generate many environmental problems such as habitat degradation, facilitating the occurrence of new biological invasion events (Biondi, Pedrosa and Macedo, 2008). The Atlantic Forest has been suffering with degradation of their ecosystems and it is exacerbated by the spread of invasive species, that according Westbrooks (cited by Santana and Encinas, 2008), against other environmental problems, biological contamination tends to multiply constantly and quickly, blocking the recovery of affected ecosystems.

One of the alien species with rigorous impacts at the Atlantic Forest's ecosystems is Acacia mangium Willd, a perennial tree of Fabaceae family and original from Australia, Papua New Guinea, Indonesia and Maluku Islands. Popularly known as acacia, this specie was widely disseminated as an alternative to environmental restoration and erosion control (Matthews, 2005; Elesbonet al., 2015) and like any invasive species it shows rapid growth, low nutrient 
requirements and may contribute to elevate the soil acidity (Attias, Siqueira and Bergallo, 2013). Its elevated invasion capacity contributed to occupy even protected areas and affect negatively the local biodiversity; besides, it's great resistance difficult its elimination and hinders any management and restoration action in this areas. Therefore, studies that aimed at a deeper understanding of the invasion mechanisms used by alien species are critical in the search for solutions to this serious environmental problem.

Thus, this study aimed to evaluate the allelopathic potential of Acacia mangium Willd on Lactuca sativa and verify if it can be used as a biological control of two other invasive species, Leucaena leucocephala and Urochloa brizantha.

\section{METHODOLOGY}

\subsection{Plant material and preparation of ethanolic extract}

For the obtainment of ethanolic extract, leaves of A. mangium Willd were collected in march 2014 (summer season) at Parque Estadual de Itaúnas, a protected area in Conceição da Barra city, Espírito Santo, Brazil and dried at room temperature. Then, they were pulverized in industrial blender low speed and $2 \mathrm{~kg}$ of that material was macerated to exhaustion in ethyl alcohol 99,3 (INPM) for five days in the dark. After, the material was filtered and concentrated on arotary evaporator for ethanol elimination.

\subsection{Phytochemical profile}

The phytochemical profile was characterized by preliminary phytochemical tests to identify major metabolites classes. Was evaluated the presence of flavonoids, triterpenes, alkaloids, saponins, tanins, anthraquinones, coumarins and steroids.

\subsection{Allelopathic bioassay}

In order to test whether chemical compounds in leaves of A. mangium Willd may have phytotoxic activity on the germination response and early seedling growth of plant species, was designed a laboratory bioassay as following.

Thirty seeds of each plant test (Lactuca sativa, Leucaena leucocephala and Urochloa brizantha) were distributed in Petri dishes (12 cm diameter) covered with filter paper and treated with 1, 5, 10 and $50 \mathrm{mg} / \mathrm{mL}$ of the extract until the stabilization of the germination process (four days to $L$. sativa and ten days to L. leucocephala and $U$. brizantha). Control seedling was treated only with deionized water. 
The experiments were carried out under natural light and at room temperature; each 24 hours was counted the number of germinated seeds and the length of the radicles measured. The parameters analyzed were:

-Germination index $(\mathrm{GI})=($ number of germinated seeds /total number of seeds $) \times 100$.

-Allelopathic index $(\mathrm{AI})=\left((\mathrm{Gc}-\mathrm{Gt})^{*} 100\right) / \mathrm{Gc}$,

Where $\mathrm{Gc}$ is the germination of the control and $\mathrm{Gt}$ is the germination of the treatment.

-Germination speed index $(\mathrm{GSI})=\sum(\mathrm{ni} / \mathrm{ti})$

Where $n i$ is the number of seed that germinated in the time $\mathrm{i} ; t i$ is the time after the test begun; $i$ =1-4 days or 1-10 day, depending on the plant tested.

-Germination mean time $(\mathrm{GMT})=(\Sigma \mathrm{niti}) / \Sigma \mathrm{ni}$,

Where $n i$ is the number of germinated seeds by day; $t i$ is the incubation time; and $i=1-4$ days or 1-10 day, depending on the plant tested.

- Germination mean speed $(\mathrm{GMS})=1 / \mathrm{t}$,

Where $t$ is germination mean time.

- Radicles mean length $=\left(\sum \mathrm{Cmi}\right) / \mathrm{t}$,

Where $C m i$ is mean length in day $\mathrm{i} ; t$ is the experimental time; and $i=1-4$ days or $1-10$ day, depending on the plant tested.

- Radicles growth speed index $(\mathrm{RGSI})=\sum(\mathrm{ci} / \mathrm{ti})$,

Where $c i$ is mean growth in time $\mathrm{i}$; $t i$ is the time after the test begun; and $i=1-4$ days or 1-10 day, depending on the plant tested.

\subsection{Statistical analysis}

All the experiments were conducted in triplicate and the results were subject by ANOVA and Tukey test; the level of significance was fixed at $\mathrm{p}<0.05$.

\section{RESULTS}

In table 1 are described the $\mathrm{pH}$ values found for the tested concentrations of leaf extracts of $A$. mangium Willd. $\mathrm{pH}$ values founded were between 4, 7 and 5, 31. As the phytochemical analysis, preliminary tests were positive for the presence of triterpens, saponins and tanins. 
International Journal of Agriculture and Environmental Research

ISSN: 2455-6939

Volume: 06, Issue: 05 "September-October 2020"

Table 1: pH values of $A$. mangium Willd leaves extract in $1,5,10$ e $50 \mathrm{mg} / \mathrm{mL}$

\begin{tabular}{ccc}
\hline TREATMENT & $\begin{array}{c}\text { CONCENTRATION } \\
(\mathbf{m g} / \mathbf{m L})\end{array}$ & $\mathbf{p H}$ \\
\hline $\mathrm{NC}\left(\right.$ deionized $\left.\mathrm{H}_{2} \mathrm{O}\right)$ & - & 6,03 \\
\hline & 1 & 5,31 \\
A. mangium Willd extract & 5 & 4,70 \\
& 10 & 4,80 \\
& 50 & 4,96 \\
\hline
\end{tabular}

The table 2 shows the germination and allelopathic index for seeds treated with A. mangium extract. For L. sativa, there was a significant reduction in germination when received the 5and $10 \mathrm{mg} / \mathrm{mL}$ concentrations; in the highest concentration tested $(50 \mathrm{mg} / \mathrm{mL})$ there was complete inhibition of germination process, showing the toxicity of the extract tested. Values for allelopathic index increased as the germination percentage reduced and reached values above $50 \%$ from $5 \mathrm{mg} / \mathrm{mL}$.

Table 2: Germination (GI) and allelopathic index (AI) to seeds of Lactuca sativa, Leucaenaleucocephala and Urochloa brizantha treated with negative control and four concentrations $(1,5,10$ e $50 \mathrm{mg} / \mathrm{mL})$ of $A$. mangium Willd leaves extracts. Different letters indicate significant differences according to Tukey test at $5 \%$ of probability

\begin{tabular}{ccccc}
\hline Plant test & $\begin{array}{c}\text { Concentration } \\
(\mathbf{m g} / \mathbf{m L})\end{array}$ & $\begin{array}{c}\text { Germinated } \\
\text { seeds }\end{array}$ & GI (\%) & AI (\%) \\
\hline NC L. sativa & - & 85 & $94,44 \mathrm{a}$ & - \\
\hline \multirow{2}{*}{ L. sativa } & 1 & 81 & $90,00 \mathrm{ab}$ & 4,70 \\
& 5 & 2 & $2,22 \mathrm{~b}$ & 97,64 \\
& 10 & 8 & $8,88 \mathrm{~b}$ & 90,59 \\
NC L. leucocephala & 50 & 0 & $0,00 \mathrm{~b}$ & 100,00 \\
\hline & - & 67 & $74,44 \mathrm{a}$ & - \\
\hline \multirow{2}{*}{ L. leucocephala } & 1 & 71 & $78,88 \mathrm{a}$ & $-5,96$ \\
& 5 & 66 & $73,33 \mathrm{a}$ & 1,49 \\
& 10 & 65 & $72,22 \mathrm{a}$ & 2,98 \\
& 50 & 59 & $65,55 \mathrm{a}$ & 11,94 \\
\hline
\end{tabular}


International Journal of Agriculture and Environmental Research

ISSN: 2455-6939

Volume: 06, Issue: 05 "September-October 2020"

\begin{tabular}{ccccc}
\hline NC $U$. brizantha & - & 60 & $66.66 \mathrm{a}$ & - \\
\hline \multirow{3}{*}{ U. brizantha } & 1 & 35 & $38,89 \mathrm{~b}$ & 41,66 \\
& 5 & 46 & $51,11 \mathrm{ab}$ & 23,33 \\
& 10 & 40 & $44,44 \mathrm{ab}$ & 33,33 \\
& 50 & 25 & $27,78 \mathrm{~b}$ & 58,33 \\
\hline
\end{tabular}

Instead of $L$. sativa, the germination capacity of $L$. leucocephala seeds were not affected by the extracts and showed negative values of AI when $1 \mathrm{mg} / \mathrm{mL}$ was used, demonstrating its positive effect on germination. For $U$. brizantha, another alien species, the extract reduced the GI in concentrations of 1 and $50 \mathrm{mg} / \mathrm{mL}$ but had no significant changes in AI except in the highest concentration.

For the Germination speed index (GSI), L. sativa suffered a significant decline in this parameter when treated with 5 and $10 \mathrm{mg} / \mathrm{ml}$ of extract (fig 1). For the alien species, seeds L. leucocephala had no changes in GSI but $U$. brizantha was affected in all concentrations, i.e, the average days required for germination of that species was lower than the control.

Fig. 1: Germination speed index (GSI) of seeds treated with negative control (NC) and four concentration (1, 5, 10 e $50 \mathrm{mg} / \mathrm{mL})$ of $A$. mangium Willd extract, where (a) - Lactuca sativa; (b) - Leucaena leucocephala; and (c) - Urochloabrizantha

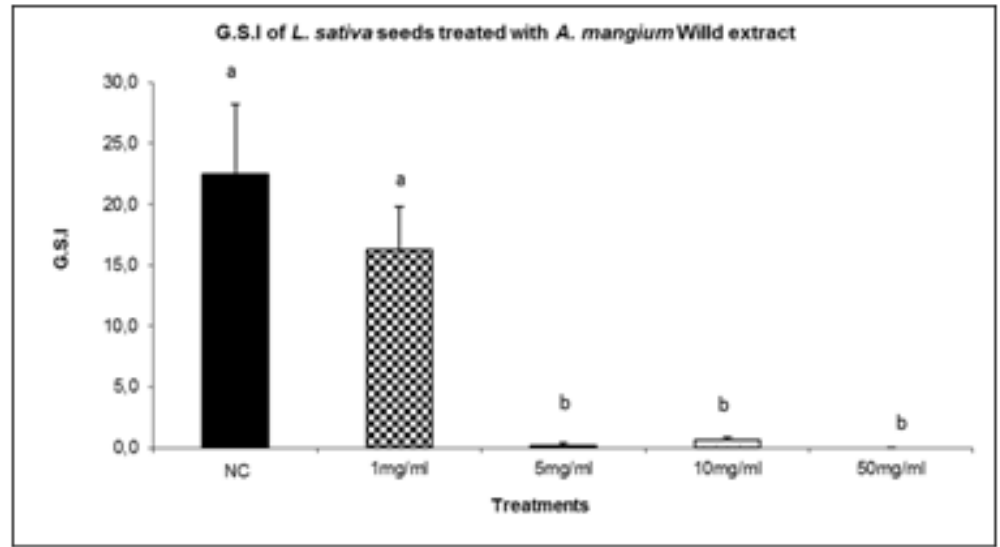

(a) 
International Journal of Agriculture and Environmental Research

ISSN: 2455-6939

Volume: 06, Issue: 05 "September-October 2020"

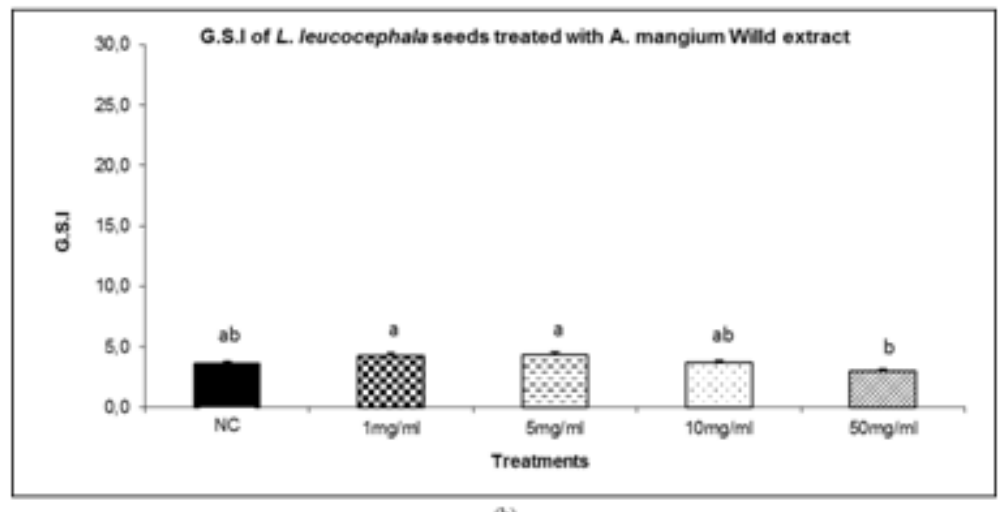

(b)

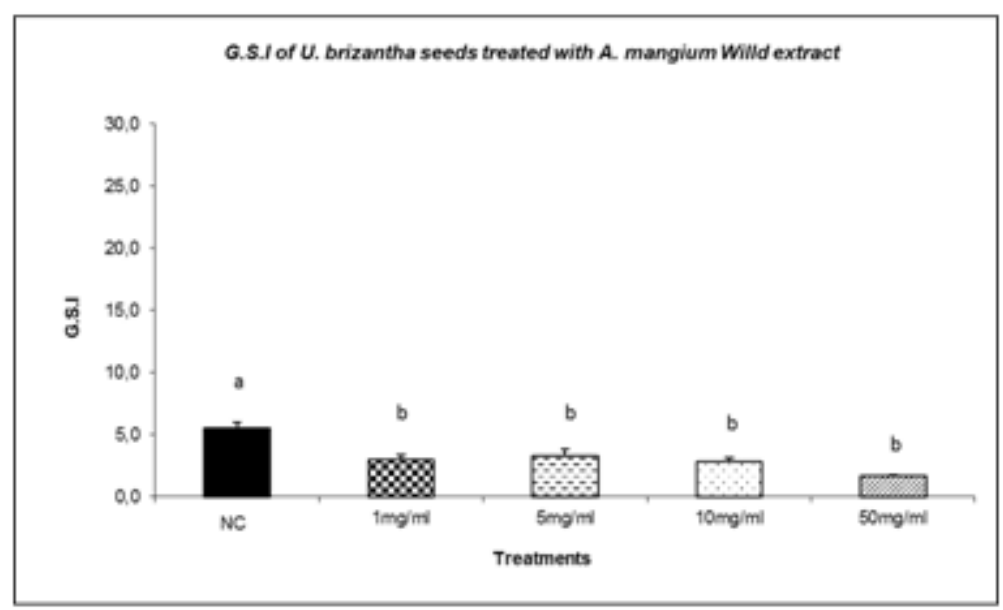

(c)

In fig 2 and 3 are described the results to Germination mean time (GMT) and Germination mean speed (GMS). To L. sativa there was no significant change in TMG while the VMG decrease at concentrations of 5 and $10 \mathrm{mg} / \mathrm{mL}$. U. brizantha had no difference for both parameters when compared to control. To L. leucocephala only the seeds that received $5 \mathrm{mg} / \mathrm{mL}$ of extract had the GMT altered when none treatment changed the GMS. 
Fig. 2: Germination mean time (GMT) of seeds treated with negative control (NC) and four concentration (1, 5, 10 e $50 \mathrm{mg} / \mathrm{mL}$ ) of A. mangium Willd extract, where (a) - Lactuca sativa; (b) - Leucaenaleucocephala; and (c) - Urochloabrizantha

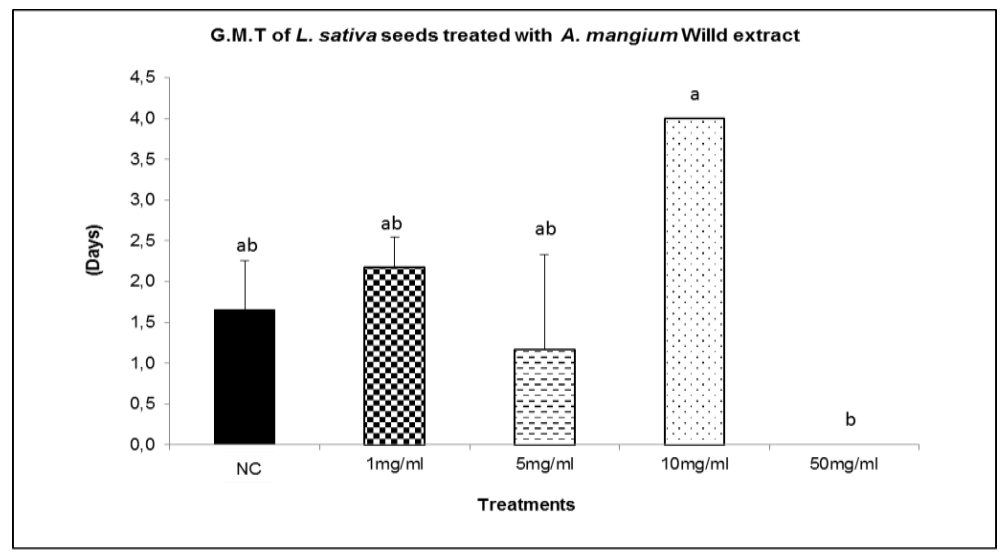

(a)

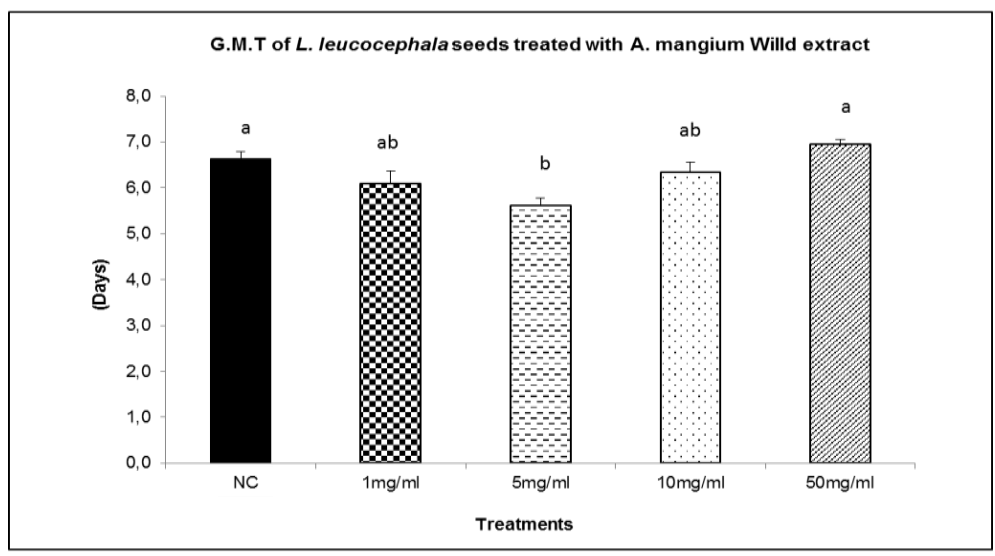

(b)

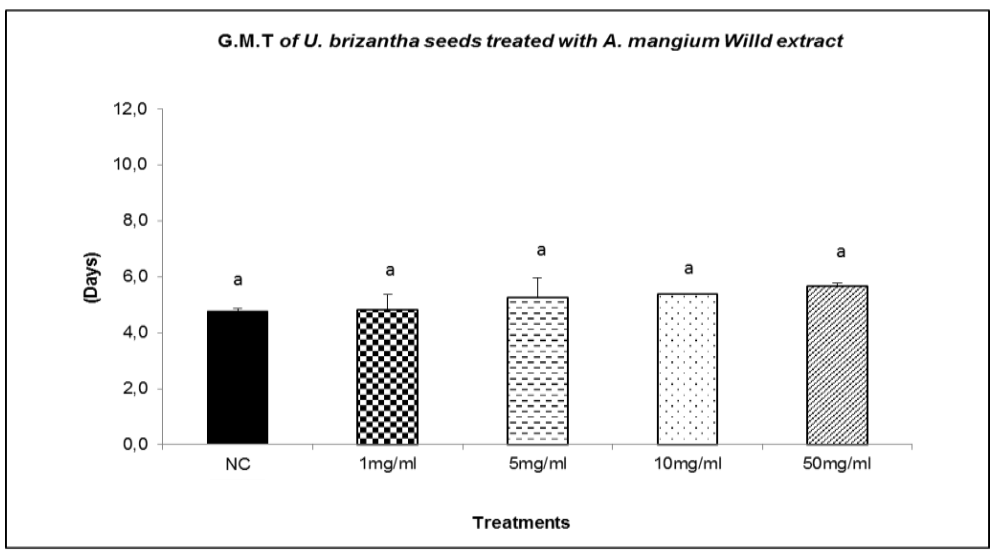

(c) 
Fig. 3: Germination mean speed (GMS) of seeds treated with negative control (NC) and four concentration (1, 5, 10 e $50 \mathrm{mg} / \mathrm{mL})$ of A. mangium Willd extract, where (a) - Lactuca sativa; (b) - Leucaenaleucocephala; and (c) - Urochloabrizantha

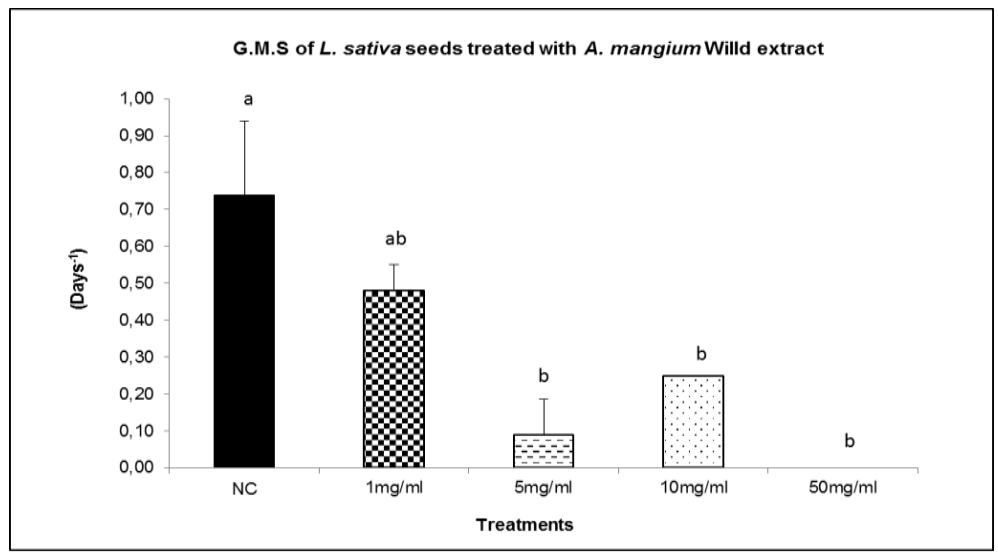

(a)

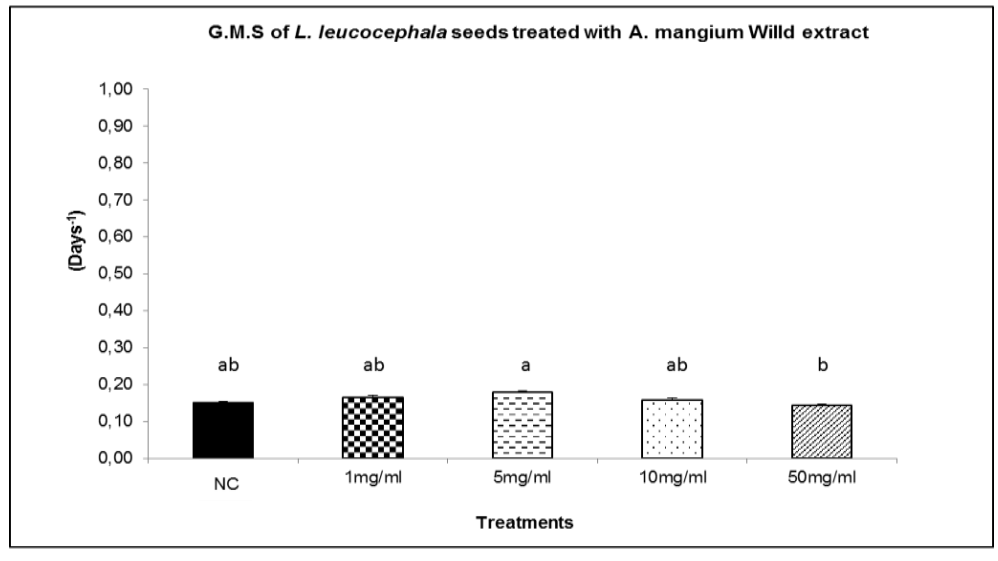

(b)

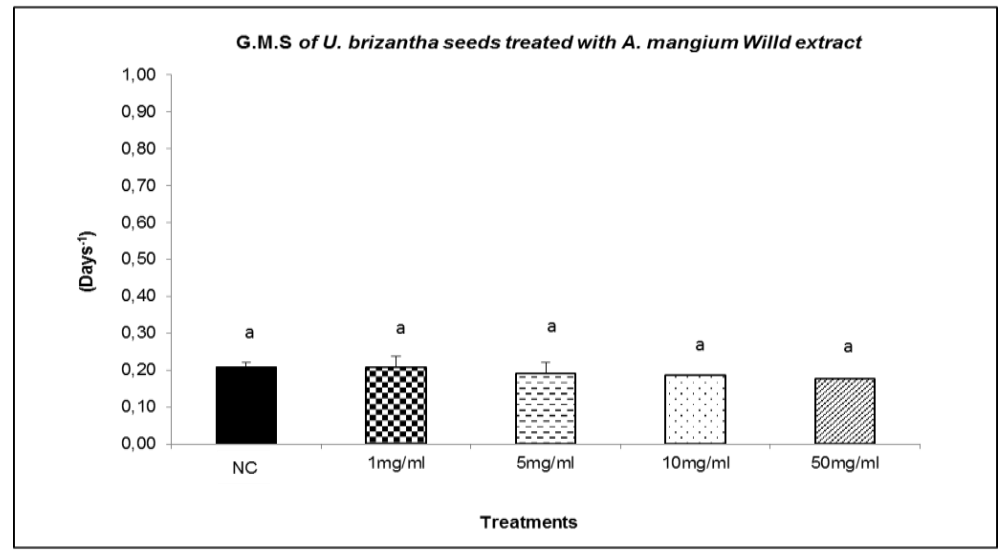

(c) 
About initial development of the radicles, L. sativa had a decrease in its length when subjected to the treatment with 5 e $10 \mathrm{mg} / \mathrm{mL}$ (fig 4), along with the radicles growth speed index (fig 5). To $L$. leucocephala the radicles treated with the extract presented a length decrease only in $50 \mathrm{mg} / \mathrm{mL}$ but the speed of its development was affected from $5 \mathrm{mg} / \mathrm{mL}$; those concentrations also decreased the $U$. brizantha radicles length and speed growth index along with 10 and $50 \mathrm{mg} / \mathrm{mL}$.

Fig. 4: Radicle mean length (RML) of seeds treated with negative control (NC) and four concentration (1, 5, 10 e $50 \mathrm{mg} / \mathrm{mL}$ ) of $A$. mangium Willd extract, where (a) - Lactuca sativa; (b) - Leucaena leucocephala; and (c) - Urochloabrizantha

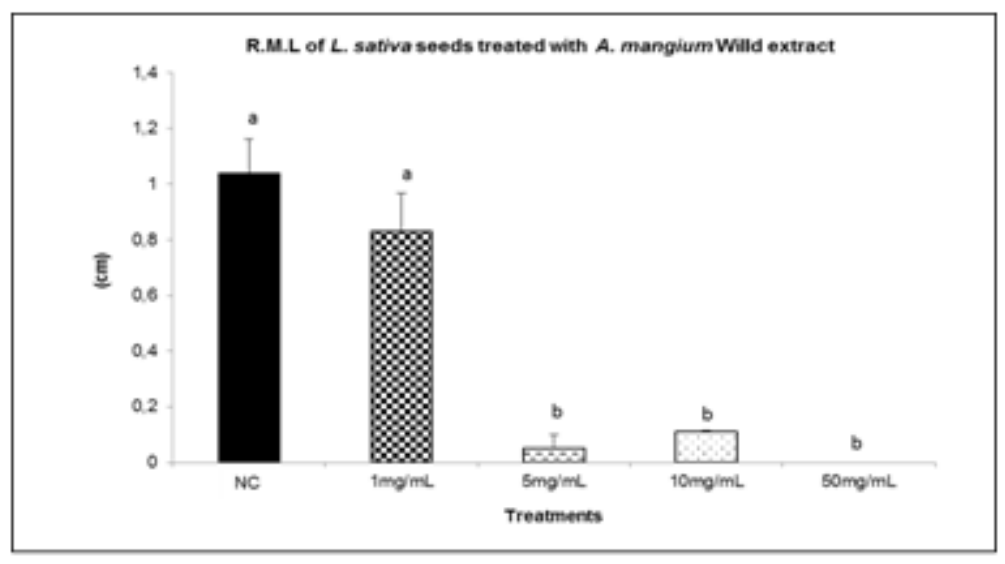

(a)

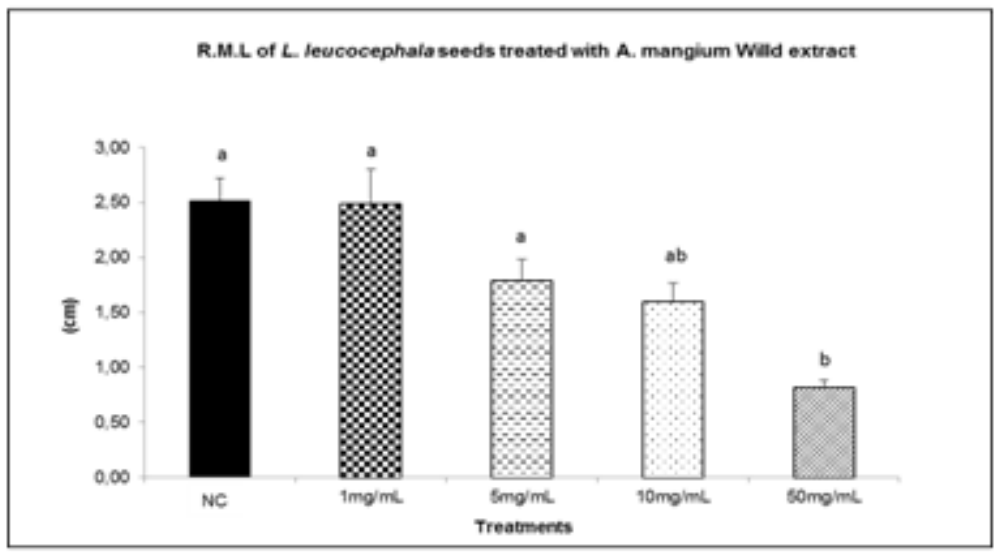




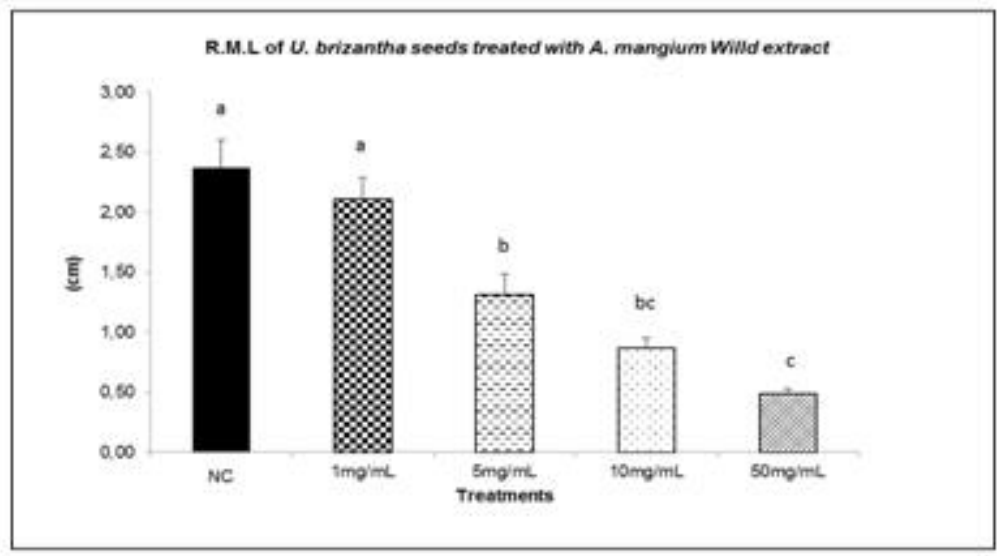

(c)

Fig 5: Radicle growth speed index (RGSI) of seeds treated with negative control (NC) and four concentration $(1,5,10$ e $50 \mathrm{mg} / \mathrm{mL}$ ) of A. mangium Willd extract, where (a) - Lactuca sativa; (b) - Leucaena leucocephala; and (c) - Urochloabrizantha

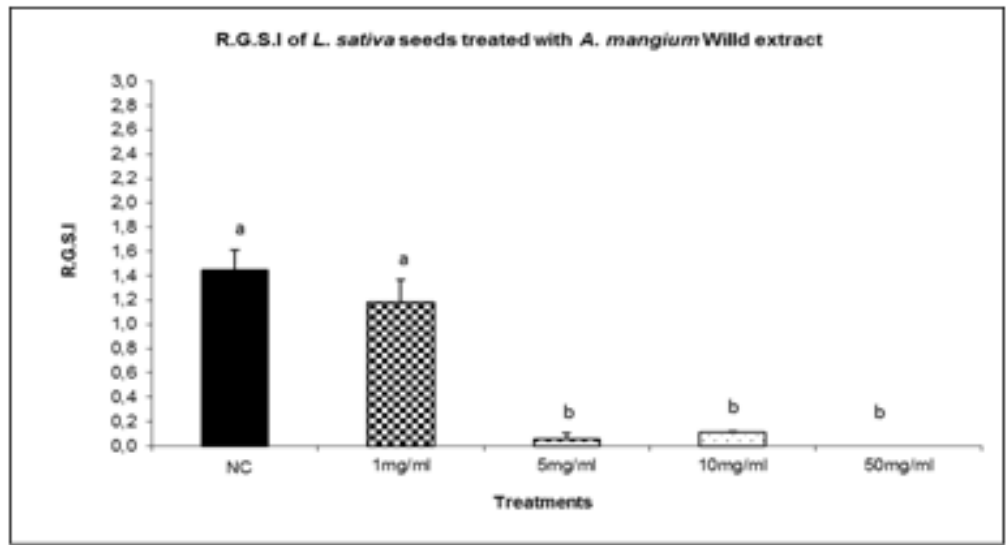

(a)

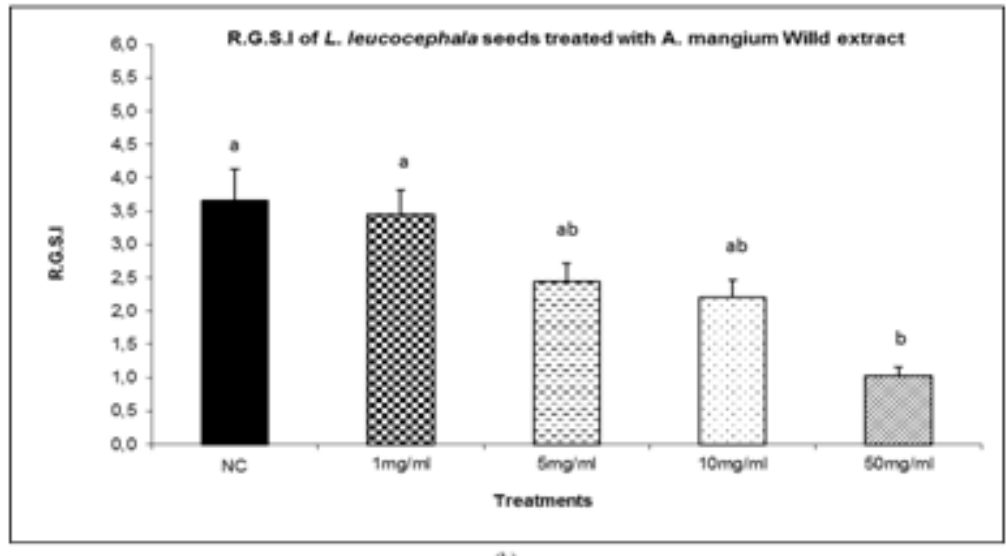

(b) 


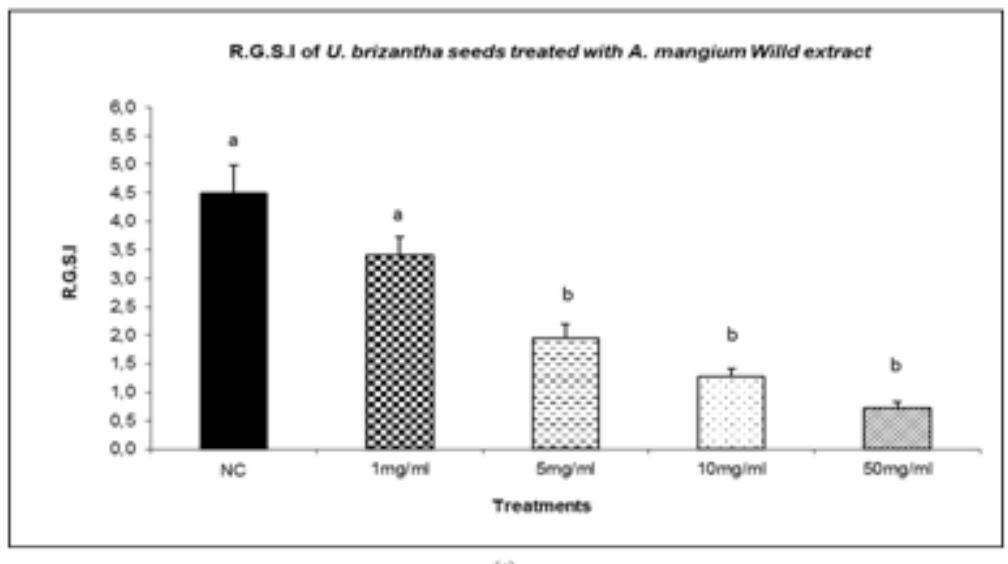

(c)

\section{DISCUSSION}

The $\mathrm{pH}$ values obtained in this work are considered ideal for promoting germination, since, according to Silveira, Maia and Coelho (2012), pH below 4.0 and greater than 10 affect negatively the process of radicle emission and even the development of seedlings. Verification of $\mathrm{pH}$ is important since solutes such as sugars and organic acids present in the extracts can mask the allelopathic effects or cause false positive results. The $\mathrm{pH}$ of the water also is within the parameters recommended by Rules for Seed Analysis (RSA), which introduced a range between 6.0 and 7.5 for germination tests (Brasil, 2009).

The results obtained to L. sativa demonstrate the allelopathic potential of A. mangium Willd extract since the germination capacity was affected from $5 \mathrm{mg} / \mathrm{mL}$; when was applied the highest concentration, the larger amount of allele chemicals prevented the germination. According Balsalobre et al. (2006), AI values above $50 \%$ can be considered as significant for allelopathic effect, what happened from $5 \mathrm{mg} / \mathrm{mL}$, confirming the allelopathic potential of A. mangium extract. When the germination speed index (GSI) is evaluated and compared with the germination index it note that besides to interfere with the germination ability of seed the extract is also capable to slowing the development speed of radicles until its complete inhibition in $50 \mathrm{mg} / \mathrm{mL}$. The extract reduced the VMG at concentrations of 5 and $10 \mathrm{mg} / \mathrm{mL}$ demonstrating that the seeds that got overcome the obstacle of germination did it with a higher speed than the control. About the radicle development, the data corroborate the allelopathic effect of the extract, since even those seeds that were able to overcome the deleterious effects of the extract in the first phase of development (i.e, germination) had not only its size committed but the time for its growth was significantly delayed.

According Jansen (apudSantana and Ranal, 2004), the germination analysis becomes complete when includes besides the germination its average speed and the average time at which the 
International Journal of Agriculture and Environmental Research

ISSN: 2455-6939

Volume: 06, Issue: 05 "September-October 2020"

process occurred. In this work it was evident because was possible evaluate the allelopathic action of the extract in many ways and provide a broader view of the process.

An investigation with another species of acácia (A. pennatula Benth) made by Peguero et al (2012) found that the leaf extract did not influence the germination of three indigenous species but considerably reduced root development by modifying the allocation of biomass and reduce by $30 \%$ these survival when planted on its canopy.

In turn, the influence of the extract on the L. leucocephala germination capacity, germination speed index and germination mean speed was null, demonstrate the resilience of this alien species, which explains its survival even in the most inhospitable places, such as sewer ditches, border of contaminated rivers, etc. Only the GMT was affected in $5 \mathrm{mg} / \mathrm{mL}$, i.e. the mean of number of days required for germination of that seed was lower than the control.

This result is atypical because the expected pattern of the curve is sigmoid, where low concentrations of the agents exert no effect, but - as they rise - the results become significant, until reaching a saturation point (Reynolds, 2010; Davidson, 2014). In the case of $L$. leucocephala, this curve of concentration-response is called "U-shape", when the optimum concentration of extracts was achieved on the basis of the curve (in this case $5 \mathrm{mg} / \mathrm{mL}$ ) and from that point the effect was no significant. According Baldi and Bucherelli (2005), this response can be explained by the interaction between the metabolites present in the extracts and the organism submitted to treatment, so that a low dose stimulate the release of cellular compounds that will act producing significant effect; however, as to elevate the concentrations and, therefore, the amounts of metabolites occurs greater release of these substances which, instead of enhancing the effect in a feedback mechanism can stimulate or inhibit the production of another, resulting in the loss of effect achieved at lower concentrations.

As for the initial development, the radicle length and the speed of this growth only were affected in $50 \mathrm{mg} / \mathrm{mL}$, i.e, when the allelochemicals were in high quantity.

The germination time recommended by RSA to $U$. brizantha is 21 days; however, GasparOliveira et al. (2008) showed that this period can be reduced for 11 days or less, since occurs the stabilization of germination process. In this work, this fact occurred in 10 days. The results show that it was more sensitive to the A. mangium Willd extract since, instead L. leucocephala, the GSI was affected at all concentrations, although there has been significant change in the GMT and GMS parameters. The radicles also were affected by the extract more than L. leucocephala (from $5 \mathrm{mg} / \mathrm{mL}$ ).

Allelopathy, process by which the secondary metabolic products of a particular plant are released preventing the germination and development of other plants (Maraschin-Silva and Áquila, 2006), 
is characteristic of many plant species; however, data for invasive species are still scarce, which impedes understanding of the mechanisms introduced by them to reach success in the biological invasion process.

Lorenzo et al (2011) work is one of the few exceptions to these fact when reporting the involvement of allelopathic mechanisms of Acacia dealbata Link on photosynthetic efficiency and respiratory rate of four native species in northeastern Spain; moreover, the work also shows that some species are more affected than others, corroborating the different results of this work was to test the extract of A. mangium Willd in three different organisms.

When comparing the results of the application of the extract on too invasive species $L$. leucocephala and $U$. brizantha it is observed that the first species was less sensitive to allelochemicals than the second, showing that $L$. leucocephala has greater resistance to allelochemicals present in extracts leaf of the test species than $U$. brizantha, what can explain its presence in practically all environmental.

In conclusion, the extract of A. mangium Willd demonstrate an allelopathic potential even on other alien species but was evident to the importance of evaluating various parameters to assess allelopathy since the allelochemicals can affect some aspects of plant biology and not have influence on others; was clear too that each specie react in a different way at the same substance. The resilience of $L$. leucocephala shows the capacity of the alien species in resist to adverse conditions, an important feature to guarantee their success in an invasion process.

\section{REFERENCES}

Alizadeh O. (2011) Exploitation of allelopathy in agriculture. Advances in Environmental Biology 5(7): 1559-1562.

Attias N,Siqueira MF, BergalloHG (2013) Acácias Australianas no Brasil: Histórico, Formas de Uso e Potencial de Invasão. Biodiversidade Brasileira. Brasília 3(2):74-96.

Baldi E, Bucherelli C (2005) The inverted "u-shaped" dose-effect relationships in learning and memory: Modulation of Arousal and Consolidation. NonlinearityBiolToxicol Med. 3:921.

Balsalobre L Cet al (2006) Ação alelopática do arilo das sementes de Passiflora edulis Sims e Passiflora alata Dryand. $19^{\mathrm{a}}$ RAIB, v.68, appendage 2, http://www.biologico.sp.gov.br/biologico/v68_supl_raib/283.PDF. Accessed 20 March 2014. 
International Journal of Agriculture and Environmental Research

ISSN: 2455-6939

Volume: 06, Issue: 05 "September-October 2020"

Barnes MA (2014) Invasion biology: a very brief history.http://www.pierisproject.org/coolstuff/invasion-biology-a-very-brief-history. Accessed 08 December 2015.

Biondi D,Pedrosa-MacedoJH (2008) Plantas invasoras encontradas na área urbana de Curitiba (PR). Floresta 38(1):129-144.

Brasil (2009) Regras para análise de sementes. MAPA/ACS, Brasília.

Cadotte MW, Mcmahon SM, Fukami T (2005) Conceptual ecology and invasions biology: reciprocal approaches to nature. Kluwer Publishers, London.

Ceccon E (2013) Restauración en bosques tropicales: Fundamentos ecológicos, prácticos y sociales. CRIM-Ediciones Díaz de Santos, Colômbia.

Cheng F,Cheng Z (2015) Research Progress on the use of Plant Allelopathy in Agriculture and the Physiological and Ecological Mechanisms of Allelopathy. Frontiers in Plant Science.doi: $10.3389 /$ fpls.2015.01020.

Davidson J (2014) A century of homeopaths: their influence on medicine and health. Springer Science \& Business Media.

Elesbon AAA et al. (2015) Diagnóstico Científico do Rio Doce. Inova, Colatina.

Gaspar-Oliveira CM et al. (2008) Duração do teste de germinação de Brachiariabrizantha cv. Marandu (Hochst. ex A. Rich.) Stapf. RevBras Sementes 30(3):30-38.

Lima AA et al. (2004) Manejo de plantas infestantes na cultura do maracujá amarelo. Embrapa.http://www.cnpmf.embrapa.br/publicacoes/circulares/circular_70.pdf. Accessed 20 January 2014.

Lorenzo P et al. (2011) Allelopathic interference of invasive Acacia dealbata Link on the physiological parameters of native understory species. Plant Ecol. doi 10.1007/s11258010-9831-9.

Lorenzo P, Gonzáles L (2010) Alelopatía: una característica ecofisiológica que favorece la capacidad invasora de las especies vegetales. Ecosistemas 19(1):79-91.

Lowe S et al. (2004) 100 de las Especies Exóticas Invasoras más dañinas del mundo: Una selección del Global Invasive Species Database. Hollands Printing Ltd, New Zeland. http://www.issg.org/bookletS.pdf. Accessed 16 November 2015. 
International Journal of Agriculture and Environmental Research

ISSN: 2455-6939

Volume: 06, Issue: 05 "September-October 2020"

Maraschin-Silva F, Áquila MEA. (2006) Potencial alelopático de espécies nativas na germinação e crescimento inicial de Lactuca sativa L. (Asteraceae). ActaBot. Bras. 20(1):61-69.

Mathias C, Rouifed S, Puijalon S et al. (2015) Allelopathic effect of a native species on a major plant invader in Europe. Sci Nat. doi 10.1007/s00114-015-1263-x.

Matos DMS, PivelloVR (2009) O impacto das plantas invasoras nos recursos naturais de ambientes terrestres - alguns casos brasileiros. Cienc Cult.61(1):27-30.

Matthews S (2005) América do Sul invadida: a crescente ameaça das espécies exóticas invasoras. Programa Global de Espécies Invasoras - GISP.

Meiners SJ, Kong $\mathrm{CH}(2012)$ Introduction to the special issue on allelopathy. Plant Ecol. doi 10.1007/s11258-012-0156-8.

Moro MF et al. (2012) Alienígenas na sala: o que fazer com espécies exóticas em trabalhos de taxonomia, florística e fitossociologia? Acta Bot Bras. 26(4): 991-999.

Peguero G et al. (2012) Allelopathic potential of the neotropical dry-forest tree Acacia pennatula Benth.: inhibition of seedling establishment exceeds facilitation under tree canopies. Plant Ecol. Doi 10.1007/s11258-011-0014-0.

Petenon V, PivelloVR (2008) Plantas invasoras: representatividade da pesquisa dos países tropicais no contexto mundial. Natureza \& Conservação 6(1): 65-77.

Reichard SH, White PS (2003) Invasion biology: an emerging field of study. Ann Missouri Bot Gard. 90:64-66.

Reynolds AR (2010) Potential relevance of bell-shaped and u-shaped dose-responses for the therapeutic targeting of angiogenesis in cancer. Dose-Response 8: 253-284.

RizviSJ (2012) Allelopathy: basic and applied aspects. Springer Science \& Business Media.

Sampaio AB, Schmidt IB (2013) Espécies Exóticas Invasoras em Unidades de Conservação Federais do Brasil. Biodiversidade Brasileira. ICMBIO, Brasília.

Santana OA, Encinas JI (2008) Levantamento das espécies exóticas arbóreas e seu impacto nas espécies nativas em áreas adjacentes a depósitos de resíduos domiciliares. Biotemas 21(4): 29-38.

Santana DG, Ranal MA (2004) Análise da germinação - um enfoque estatístico. UNB, Brasília. 
Sax DF, Stachowicz JJ, Gaines SD (2005) Species invasions: Insights into ecology, evolution and biogeography. Sinauer Associates Inc.

Silveira PF, Maia SSS, Coelho MFB (2012) Potencial alelopático do extrato aquoso de folhas de Mimosa tenuiflora (Willd.) Poir. na germinação de Lactuca sativa L. BioscienceJournal 28(3):472-477.

Vitule JRS, Prodocimo V (2012) Introdução de espécies não nativas e invasões biológicas. EstudBiolAmbiente Divers.doi: 10.7213/estud.biol.7335.

Zenni RD, Ziller SR (2011) An overview of invasive plants in Brazil. Revista Brasil Bot. 34(3): 431-446, 2011. 